\title{
多連秤による改良型連続秤量法
}

\author{
田 崎 良 佑* • 山 崎 敬 則** \\ 小林 政 明***黒須 茂****
}

\section{Improved Continuous Weighing by Multi-stage Conveyor Belt Scale ${ }^{\dagger}$}

\author{
Ryosuke Tasaki*, Takanori Yamazaki**, Hideo Ohnishi***, \\ Masaaki KoBAYASHi*** and Shigeru KuROSU ${ }^{* * * *}$
}

\begin{abstract}
In this paper, we propose higher speed and highly accurate weighing method of packages during crossing a conveyor belt. Continuous weighing means that the masses of discrete packages on a conveyor belt are determined in sequence. Through the new weighing method, a weighing scale (called a multi-stage conveyor belt scale) can be created so as to adjust the conveyor belt length to the product length. In a previous paper, the masses of products have been estimated successfully as the maximum values evaluated from the output smoothed signals. However, there have been still some crucial problems that the estimation errors were sometimes getting worse. One of causes has been due to the fact that the output signals had several peak values like a winding path. In this paper, our interest is directed to solve many technical problems when we put the multi-stage conveyor belt scale into practical use. Consequently, our weighing method proposed here is not sufficient for highly accurate weighing, but the limit of practicability has been verified by experiment.
\end{abstract}

Key Words : weighing, mass measurement, conveyor belt scale

\section{1.はじめに}

近年，物流，食品業界などにおいて，コンベアライン上に 搬送される秤量物の質量測定の高速, 高精度化の要求にとも ない,ロードセル(はかり)により科量された計測デー夕か ら, 質量をいかに効率よく推定するかが重要な課題となって いる，すでに，異なる長さ，質量の秤量物を，複数個の計量 コンベア(以下，多連科とよぶ)を配置し，科量物の長さに応 じてその出力を組み合わせた多連科による連続科量が実用に 供されている1),2).

計量コンベア上を搬送される科量物の質量測定は，動的質 量計測の分野に属し, この分野での研究は, 前田らによる

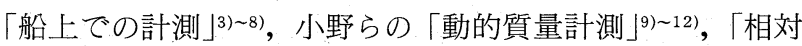
補(償法」13) 16) があり, 最近においても多くの研究が精力的

+ SICE Annual Conference 2004 in Sapporo で発表 (2004-8)

* 京都工芸繊維大学 京都市左京区松ヶ崎橋上町

** 小山工業高等専門学校 小山市中久喜 771

*** 新光電子(株) 下妻市高道祖 4219-71

****クロテック (研究所) 下館市女方 61-88

* Kyoto Institute of Technology, kyoto

** Oyama National College of Technology, Oyama

*** Shinko Co., Ltd., Shimotsuma

**** Research Inst. Crotech, Shimodate (Received May 28, 2004)

(Revised September 17, 2004)
に行なわれている。

科量物の動的質量測定では, 科量物と計量システムとから なるシステムの厳密な数学モデルが前提となる. 著者らはシ ステム全体をあまり難しくせず，できるだけ簡易化したモデ ルで一般化する方法をとる。また，FIRフィル夕によって 平滑化されたデータの最大值から科量物の質量を推定する簡 易測定法を提案し，報告している17) 20).

工業的使用条件において厳しい要求が課せられる状況下 で, 多連科は実用上の問題点が多く, 高速, 高精度化の要求 には必ずしも答えられていない.メーカ側では優れた性能を 実現するために，機構の改良などハードウェアの側面からの 改善に力が注がれているようである. 既論文 ${ }^{18)}$ では多連科 による連続科量を信号処理として捕らえ，ソフトウェアの側 面から数理的に検討した簡易測定法を提案しているが，本論 文ではこの方法の技術的な問題点を明らかし，改善策を施し た実験結果を通して多連科の実用性の限界を検証する。

\section{2. 計量システム}

コンベアライン上に搬送された物体を，連続的に秤量する 計測システムを考える. 計測システムの基本的な構成の概略 を示したのが Fig. 1 である. 荷重受部は 1 点でロードセル によって支持されたベルトコンベアであり，これを計量コン ベアとよぶ. 各計量コンベア間に配置してある光電スイッチ により，科量物の長さ，間隔，搬入してくる時刻が計測され 


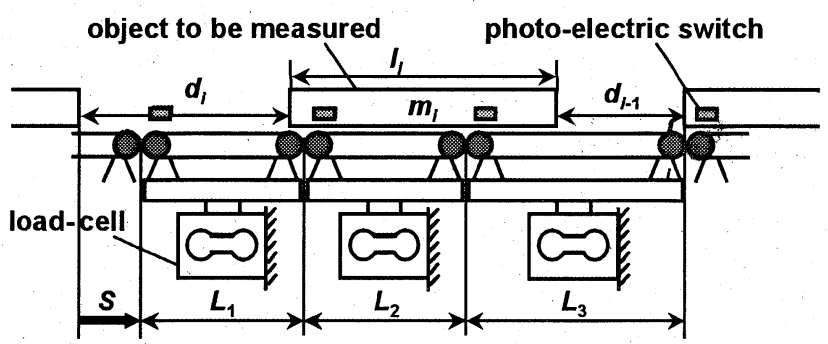

Fig. 1 Multi-stage conveyor belt scale

る. Fig. 1 において, 連続する科量物の長さ $l_{i}[\mathrm{~cm}]$, 連続 する秤量物の間隔 $d_{i}[\mathrm{~cm}]$, 計量コンベアの長さ $L_{1}=L_{2}=$ $40[\mathrm{~cm}], L_{3}=60[\mathrm{~cm}]$, 搬送速度 $v=132[\mathrm{~m} / \mathrm{min}]$ である.

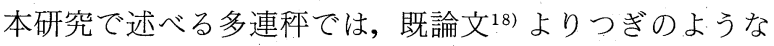
計量コンベアの組み合わせを考えている.

$20 \leq l_{i} \leq 40[\mathrm{~cm}]$ に対して単連科 $\left(L_{3}=60[\mathrm{~cm}]\right)$, $40<l_{i} \leq 60[\mathrm{~cm}]$ に対して二連科 $1\left(L_{1}+L_{2}=80[\mathrm{~cm}]\right)$, $60<l_{i} \leq 80[\mathrm{~cm}]$ に対して二連科 $2\left(L_{2}+L_{3}=100[\mathrm{~cm}]\right)$, $80<l_{i} \leq 125[\mathrm{~cm}] に$ 対して三連科 $\left(L_{1}+L_{2}+L_{3}=140\right.$ $[\mathrm{cm}])$.

一般に、ディジタルフィルタはインパルス応答が有限長で あるか無限長であるかによって，FIRフィルタとIIRフィ ル夕に分けられる. FIR フィルタは, 入力データのみで出 力が計算され, 過渡現象が持続しない. したがって, 連続科 量のように高速処理を要求される分野では FIR フィルタが 適切である. FIR フィルタの設計法については既論文 ${ }^{17)} に$ 述べたので割愛する. 通過域と阻止域の設計条件 $\left(\Omega_{p}=\right.$ $\left.0.002, \Omega_{s}=0.05\right)$ とし, 阻止域の低いエッジ周波数 $f_{s}=$ $12.5[\mathrm{~Hz}]$, パルス伝達関数の次数 $M=42$ 次の FIR プィル 夕によって, 周期 $0.5[\mathrm{~ms}]$ の測定データをダウンサンプリ ング(周期 $4[\mathrm{~ms}]$ ) してフィル夕処理を行なう。その後, 一 次系のフィルタ(しゃ断周波数 $80[\mathrm{~Hz}])$ を通過させて平滑化 する。また，二連称，三連科の場合には，各計量コンベアの 平滑化されたデー夕を足し合わせた後，再度同じ一次系フィ ル夕を通過させる。

\section{3. 実用上の問題点}

\section{1 最小間隔 (幾何学的測定可能条件)}

連続科量の高速化のためには，コンベアラインの搬送速度 $v$ を上げるか科量物の間隔をできるだけ狭くすればよいが, 搬送速度を上げると科量物が計量コンベア上に搭載される時 間が短くなり，“測定誤差をマイナス側に増大させてしまうの で，ここでは測定可能となる科量物の最小間隔を検討する。

多連科の長さを $L\left(\right.$ 三連科では $\left.L=L_{1}+L_{2}+L_{3}\right)$ とし, 多 連科の出力波形が定常值を示すのに必要な科量物の移動距離 を $S$ とする. Fig. 1 より, 質量 $m_{i}$ の科量物が多連科に搭載 し, 移動距離 $S$ を確保するための最小間隔 $d S$ はつぎのよう に書ける。

$$
2 d_{S} \geq L-l_{i}+S \quad\left(d_{S}=\min \left(d_{i-1}, d_{i}\right)\right)
$$

(1)式において $S=20[\mathrm{~cm}]$ とした場合に，各多連科におけ

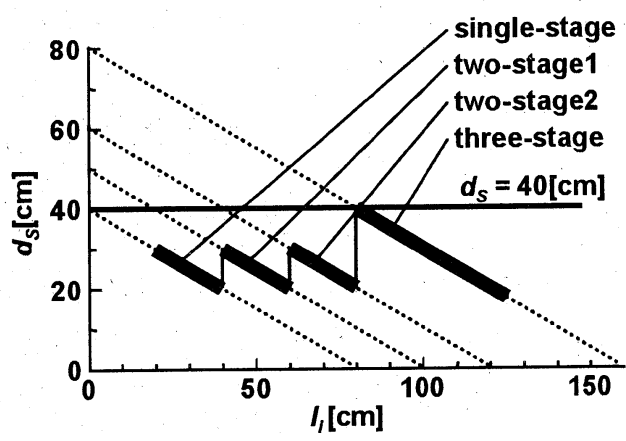

Fig. 2 Minimum space between the products

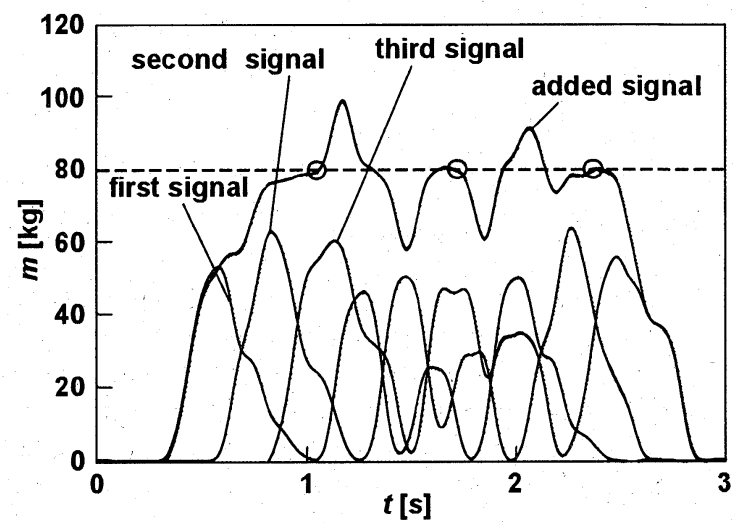

Fig. 3 Experimental result (three products in sequence)

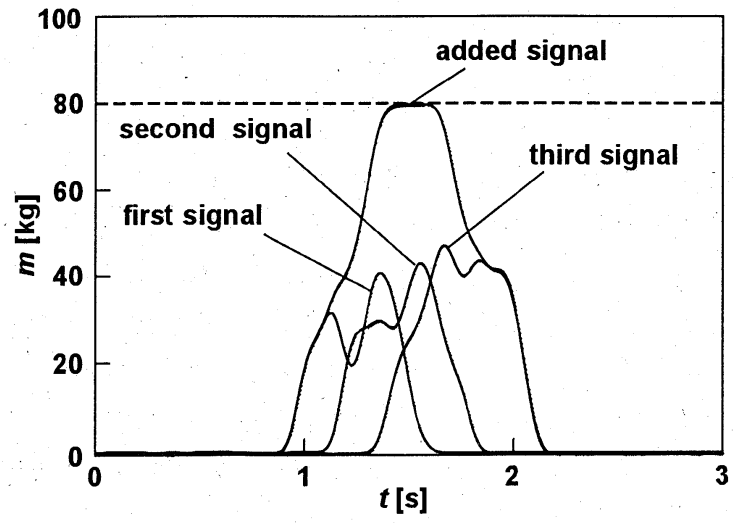

Fig. 4 Experimental result (a single product)

る最小間隔 $d_{s}$ を計算した結果を示したのが Fig. 2である. これより， $d_{s} \geq 40[\mathrm{~cm}]$ であればよいことになる。ただし， $S$ の值は $v$ によって変える必要がある。

\section{2 不等分布荷重}

多連秤からの出力を FIR，一次系フィルタによって平滑 化した測定データの最大值から，秤量物の質量を推定する簡 易測定法を明らかにしてきたが17),18)，科量物を連続して搬 送するさいに，この方法が適用できない事例が生じた。

Fig. 3 は三連秤の出力波形の一例であり, $l_{i}=100[\mathrm{~cm}]$, $m_{i}=80[\mathrm{~kg}]$ の科量物を間隔 $d_{i}=60[\mathrm{~cm}]$ で 3 個連続して搬 送したときの出力波形である．科量物の底板が平坦で荷重を 等分布荷重と考えれば，その出力波形は明確な 3 つのピーク 
值をもつが，実際の出力波形にはいくつものうねりが出現し ている。これは，科量物の底板の反りやそれぞれの計量コン ベア間の微小な段差により，計量コンベアに加わる荷重が不 等分布荷重であることに起因している.

つぎに，Fig. 3 の場合と同じ長さ，質量の科量物を単体で 搬送したさいの出力波形を Fig. 4 に示す. 各計量コンベア の出力を加えた合計の出力波形は，山の裾野を広げている. このとき，科量物が多連科から搬出される以前に，つぎの科 量物が搬入されると, Fig. 3 に示すようなうねりが出現す る。うねりは常時現われるわけではないが，科量物の間隔が 狭いほど出現頻度は増える。

\section{4. 最大值を探索する時間区間 $\boldsymbol{T}_{b}$}

Fig. 3 に示す出力波形に，科量物の正しい質量 $80[\mathrm{~kg}]$ を 示す区間があることは，破線上に示す○印から明らかであ る.このことは, 出力波形のある特定の時間範囲 $T_{b}$ 内で最 大值を探索すればよいことを示唆している。以下に述べる結 果はシミュレーションによるものであり, 計量コンベアの数 学モデル，信号処理のアルゴリズムはすでに報告してい $る^{17) ~ 19)}$. 数学モデルは質量一ばね系から構成され，科量物 の質量 $m_{i}$ が計量コンベアに搬入されたときに入力荷重の変 化となり，ロードセルの出力をもって $m_{i}$ を推定する.

\section{1 等分布荷重における最大值時刻 $T_{M}$}

多連科の出力波形において，科量物が計量コンベア上に搬 入してから最大值を示すまでの時間(最大值時刻 $T_{M}$ とよぶ) を測定する。ここでは，科量物は単体で搬送した場合を想定 している. $20 \leq l_{i} \leq 125[\mathrm{~cm}], 20 \leq m_{i} \leq 80[\mathrm{~kg}]$ についての 最大值時刻 $T_{M}$ の分布を Fig. 5 に示す。これより，す心゙て の多連科で $T_{M}$ は秤量物の長さに比例して増加していること がわかる。 $T_{M}$ についての近似式はつぎのようになる。

$$
T_{M}=a_{0}+a_{1} l_{i}[\mathrm{~s}]
$$

ここに，係数 $a_{0}, a_{1}$ を Table 1 に示す. $T_{M}$ は科量物が多連 秤のほぼ中央に位置した時刻であるから， $a_{0}, a_{1}$ の違いは各 多連科の長さの違いによる.

\section{2 不等分布荷重での最大值時刻の変動}

つぎに，Fig. 6 のような両端に質量が偏つた不等分布荷重

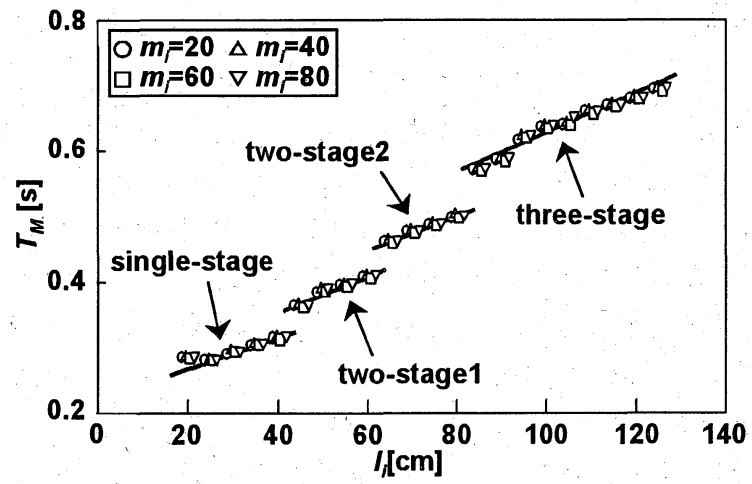

Fig. 5 Distributions of maximum times $T_{M}$ with product length $l_{i}$
をもつ科量物を考え，科量物と計量コンベアとの接触長さ $l_{c}$ ，分布荷重 $m_{a}, m_{b}\left(m_{i}=m_{a}+m_{b}\right)$ を変更して最大值時刻 の分布を調べた。ここで，秤量物は単体で流した場合を想定 し, 科量物の長さは, 単連科: $l_{i}=30[\mathrm{~cm}]$, 二連科 $1: l_{i}=$ $50[\mathrm{~cm}]$, 二連科 $2: l_{i}=80[\mathrm{~cm}]$, 三連科 $: l_{i}=110[\mathrm{~cm}]$ であ る.また, $l_{c}=0.2 l_{i} \sim 0.6 l_{i}[\mathrm{~cm}]\left(0.2 l_{i}\right.$ 刻み); $m_{a}=0.1 m_{i}$ $\sim 0.9 m_{i}[\mathrm{~kg}]\left(0.1 m_{i}\right.$ 刻み) と変更した。

Fig. 7 ( a ) （d）は，各条件において $m_{a}$ を変えたときの 最大值時刻を示した結果で，図中の実線は等分布荷重での最 大值時刻 $T_{M}$ ，破線は $T_{M} \pm 10[\mathrm{~ms}]$ を示している. 三連科に おいて $l_{i}=110[\mathrm{~cm}], m_{i}=20[\mathrm{~kg}], l_{c}=0.4 l_{i}[\mathrm{~cm}]$ の 場 合 に， $m_{a}$ を変更したときの出力波形の一例を Fig. 8 に示す. $m_{a}$ の変化とともに，最大值時刻が連続的に移動している.

Fig. 7 において $T_{M} \pm 10[\mathrm{~ms}]$ から最大值時刻が逸脱して いる測定点について説明する。とくに，Fig. 7（d)における $l_{c}=0.6 l_{i}$ では，全データがこの領域から離れたところにあ る.それはつぎの理由による.Fig. 9 は二連科 1 の実験結果 で，実線は $l_{c}=0.2 l_{i} ， m_{a}=0.1 m_{i}($ Fig. $7(\mathrm{~b})$ の $)$ の不等分 布荷重での出力波形，破線は同じ長さの科量物を等分布荷重 と想定した場合の足し合わせた出力波形を示している，不等 分布荷重での足し合わせた出力波形は，真の質量ではない ピーク值を生み出していることがわかる。このピーク值は, 質量 $m_{b}\left(=0.9 m_{i}\right)$ が 2 段目の計量コンベアへ搬入するとき の過渡応答と，1段目の計量コンベアから搬出するときの過 渡応答とが重なるときに発生している。この部分では急峻な 入力荷重が加わることによって，直線となるべき波形が曲線 となり，それらが重なることで真の質量ではないピーク值を 生み出している。しかしながら，このようなピーク值をもつ 出力波形 (実線) と等分布荷重での出力波形(破線) とが，真の 質量であるピーク值近傍で一致していることがわかる．この 事実が，うねりをもつ出力波形から正確な質量測定值を得る ための重要な情報となる，以上のことから，科量物の正確な 質量はつぎの範囲内に存在することが明らかである。

$$
T_{b} \leq T_{M} \pm 10[\mathrm{~ms}]
$$

Table 1 Coefficients $a_{0}$ and $a_{1}$

\begin{tabular}{c|c|c}
\hline \hline & $a_{0}$ & $a_{1}$ \\
\hline single-stage & 0.2187 & 0.0024 \\
\hline two-stage 1 & 0.2387 & 0.0028 \\
\hline two-stage 2 & 0.2995 & 0.0025 \\
\hline three-stage & 0.3275 & 0.0030
\end{tabular}

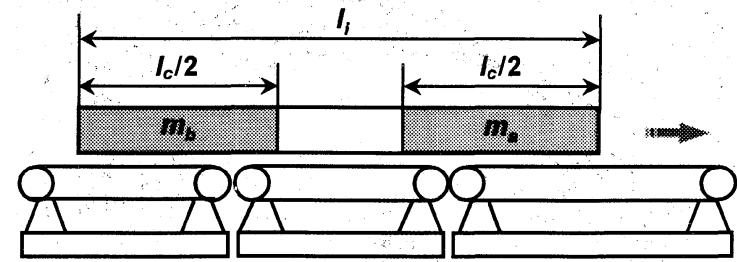

Fig. 6 Schematic view of a product with non-uniformly distributed weight 


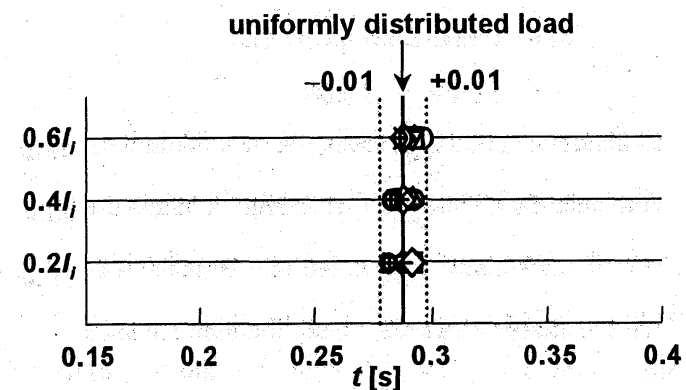

(a) single-stage conveyor belt scale

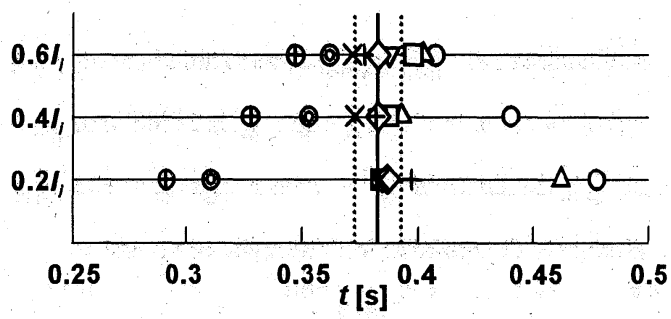

(b) two-stage 1 conveyor belt scale

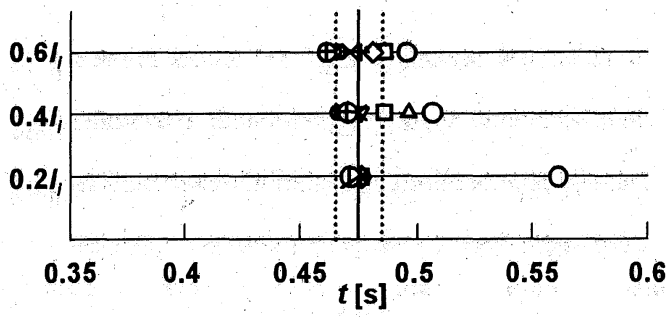

(c) two-stage 2 conveyor belt scale

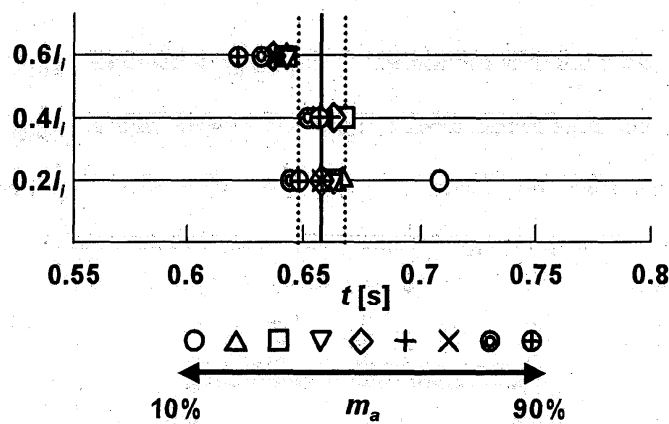

(d) three-stage conveyor belt scale

Fig. 7 Distributions of maximum times for non-uniformly distributed load

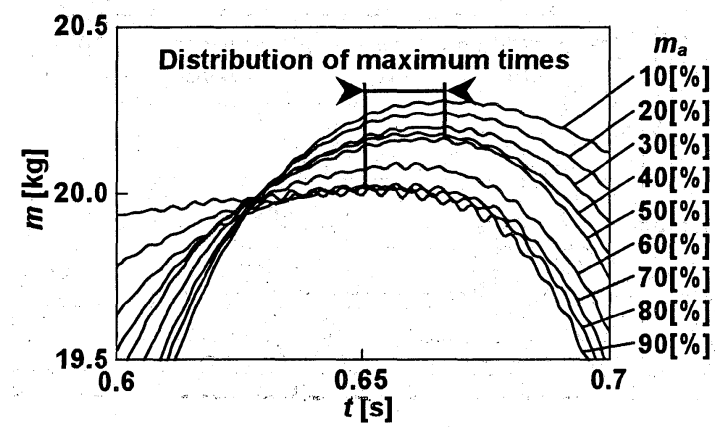

Fig. 8 Time behaviors around peak values (magnified)

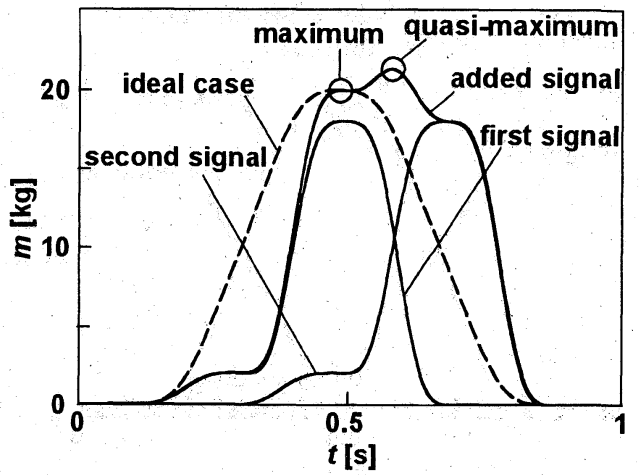

Fig. 9 Simulation result for unwanted quasi-maximum

\section{5. 多連秤における実測例}

\section{1 測定誤差率の分布}

以上の考察をもとに，多連科による測定実験を実施する。 長さと質量とが同じ科量物を 3 個連続して搬送する。ここ で, $20 \leq l_{i} \leq 130[\mathrm{~cm}]\left(10[\mathrm{~cm}]\right.$ 刻 み), $20 \leq m_{i} \leq 80[\mathrm{~kg}](20$ [kg] 刻み), $d_{1}=d_{2}=40,50[\mathrm{~cm}]$ とし, 各科量物の長さ $l_{i}$, 質量 $m_{i}$ について，同じ条件で 7 回搬送を行なっている，実 験で得られた測定誤差率 $\varepsilon[\%]$ の分布を Fig. 10 (a) (d) に示す。これらより, 要求された精度 \pm 0.7 [\%]の許容範囲 に収まっているものの，一部に逸脱したデータもある。ま

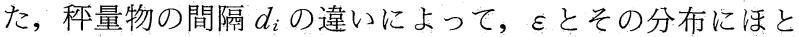
んど違いがない.

各科量物の長さ $l_{i}$ に関して, 平均誤差率 $\bar{\varepsilon}$ を求めた結果 を Table 2 に示す。これより，ほぼすべての条件におけるを が， $\pm 0.7[\%]$ の許容範囲に収まっているが，単連秤におい て $l_{i}=20[\mathrm{~cm}]$ が許容範囲をプラス側に冕脱している。これ は, $l_{i}$ が短くなると, 搬入と搬出時の入力荷重のパターンが パルス状となり, その過渡現象の影響が出てきたものと考え られる。ここで, 三連科における $l_{i}=90[\mathrm{~cm}]$ の場合に, 科 量物の間隔 $d_{i}$ の違いによって $\bar{\varepsilon}$ が最も大きく異なっている. 己れは， $d_{i}=40[\mathrm{~cm}]$ の場合に(1)式の測定可能条件をほほ 限界で満足することが原因であり，ををプラス側に大きくし ている.

\section{2 低周波ノイズによる攪乱}

実測例の中でごく少ない頻度ではあるが，要求精度から外 れたデー夕が収録された，出力波形を時系列で見ると，2〜 $13[\mathrm{~Hz}]$ の低周波ノイズによって測定データが乱されている ことが判明した。一例として， $l_{i}=50[\mathrm{~cm}], d_{i}=40[\mathrm{~cm}]$ で, $m_{i}=20[\mathrm{~kg}]$ ならびに $m_{i}=60[\mathrm{~kg}]$ の科量物を 3 個連続 して搬送したときの 1 段目の計量コンベアの出力波形を Fig. 11 (a)，（b)に示す. $m=20[\mathrm{~kg}]$ の場合では 2〜2.5 $[\mathrm{Hz}], m_{i}=60[\mathrm{~kg}]$ では 5〜6.5[Hz]の低周波ノイズによっ て出力波形が污されていることがわかる．この場合， $l_{i}=50$ [cm]であるから二連科で科量すべきである，ところが，同 じ条件で三連秤に加わる入力荷重を示したのが Fig. 12（a）， （b)である.（a) は等分布荷重，（b) は不等分布荷重 $\left(l_{c}=\right.$ 


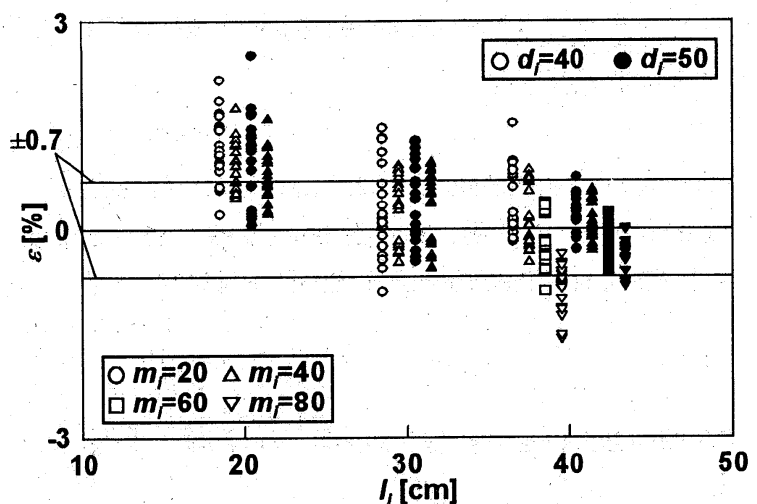

(a) single-stage conveyor belt scale

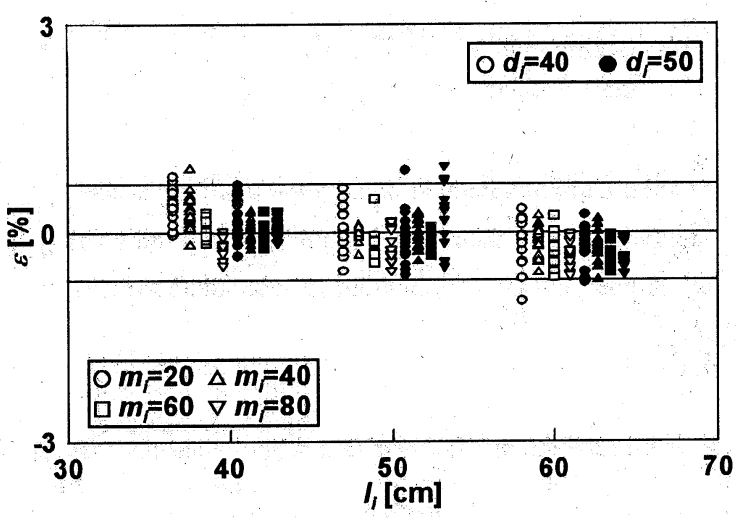

(b) two-stage 1 conveyor belt scale

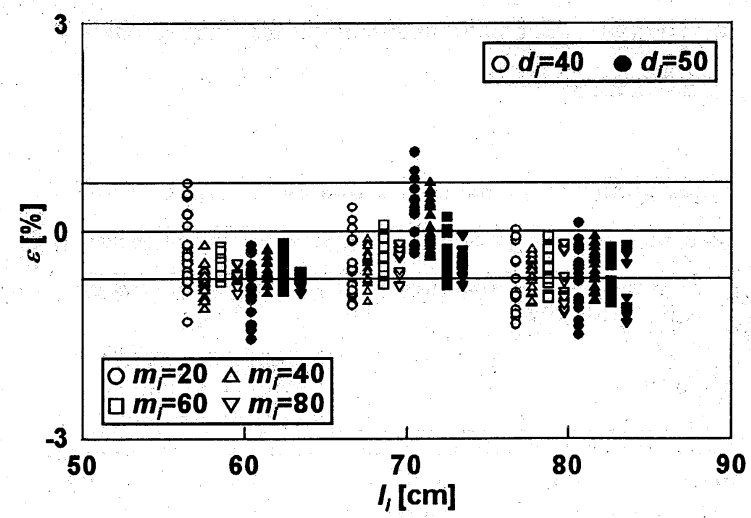

(c) two-stage 2 conveyor belt scale

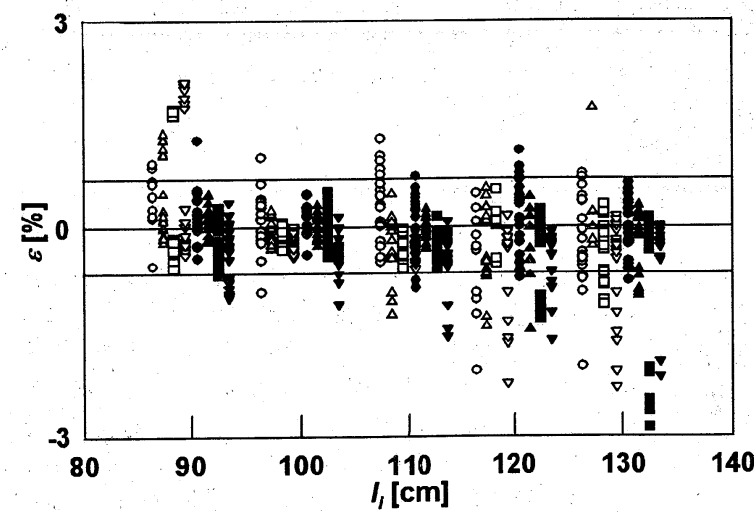

(d) three-stage conveyor belt scale

Fig. 10 Distributions of estimation errors
Table 2 Mean estimation errors

\begin{tabular}{c|c|c|c}
\hline \hline \multirow{2}{*}{$\begin{array}{c}\text { conveyor } \\
\text { belt scale }\end{array}$} & $\begin{array}{c}\text { length of } \\
\text { product }[\mathrm{cm}]\end{array}$ & \multicolumn{2}{|c}{ mean value of $\varepsilon[\%]$} \\
\cline { 2 - 4 } & $d_{i}=40[\mathrm{~cm}]$ & $d_{i}=50[\mathrm{~cm}]$ \\
\hline \multirow{4}{*}{ single-stage } & $l_{i}=20$ & 1.041 & 0.942 \\
\cline { 2 - 4 } & $l_{i}=30$ & 0.340 & 0.384 \\
\cline { 2 - 4 } & $l_{i}=40$ & -0.118 & -0.040 \\
\hline \multirow{4}{*}{ two-stage 1 } & $l_{i}=40$ & -0.153 & 0.096 \\
\cline { 2 - 4 } & $l_{i}=50$ & -0.102 & -0.019 \\
\cline { 2 - 4 } & $l_{i}=60$ & -0.228 & -0.264 \\
\hline \multirow{4}{*}{ two-stage 2 } & $l_{i}=60$ & -0.521 & -0.665 \\
\cline { 2 - 4 } & $l_{i}=70$ & -0.426 & -0.151 \\
\cline { 2 - 4 } & $l_{i}=80$ & -0.635 & -0.700 \\
\hline \multirow{5}{*}{ three-stage } & $l_{i}=90$ & 0.371 & -0.102 \\
\cline { 2 - 4 } & $l_{i}=100$ & -0.106 & -0.120 \\
\cline { 2 - 4 } & $l_{i}=110$ & -0.440 & -0.243 \\
\cline { 2 - 4 } & $l_{i}=120$ & -0.574 & -0.271 \\
\cline { 2 - 4 } & $l_{i}=130$ & -0.649 & -0.736 \\
\hline
\end{tabular}

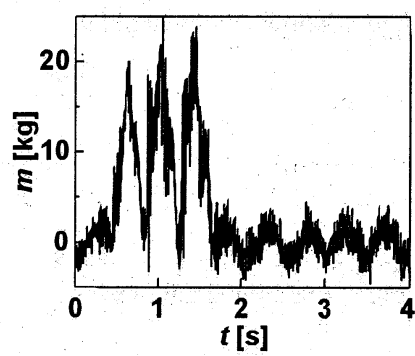

(a) $m=20[\mathrm{~kg}]$

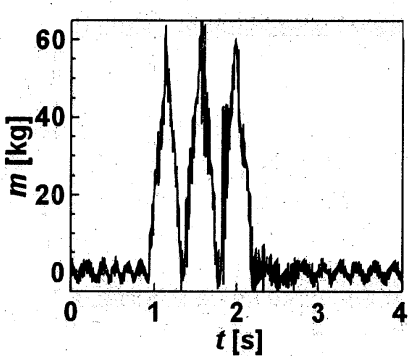

(b) $m=60[\mathrm{~kg}]$
Fig. 11 Experimental results (first-stage)

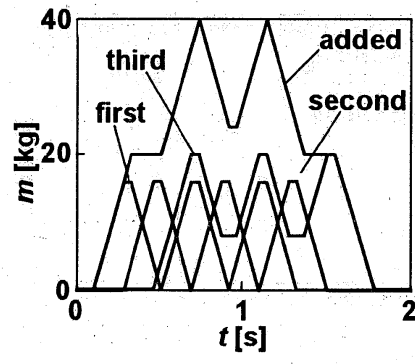

(a) $m=20[\mathrm{~kg}]$

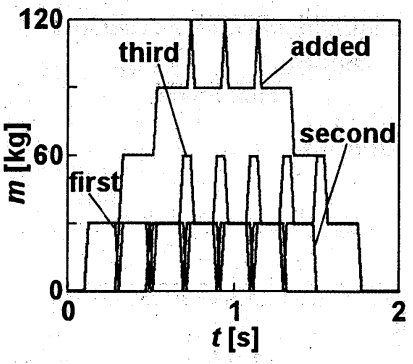

(b) $m=60[\mathrm{~kg}]$
Fig. 12 Time behavior of loading input

$\left.0.2 l_{i}, m_{a}=m_{b}=0.5 m_{i}\right)$ を想定している. 計量コンベアの 入力荷重を合計すると $2.5[\mathrm{~Hz}], 5[\mathrm{~Hz}]$ のパルス状の衝撃 力が出現している.

低周波ノイズの発生には, 入力荷重の衝撃力による影響が 考えられるものの, $6[\mathrm{~Hz}]$ 以上となると入力荷重の衝撃力 からは考えにくい.この低周波ノイズによる測定データへの 攪乱は，持続するものではなくすぐに減衰するが，少ない頻 度とはいえ質量測定には悪影響を与える。低周波ノイズの発 生に対する原因究明は今後の課題であり, 多連科の連続科量 では解決されるべきである。 


\section{6. おわりに}

本研究では，コンベアライン上に搬送される科量物の質量 を高速, 高精度で測定するために, 複数の計量コンベアの出 力を組み合わせた多連科による改良型連続科量法を提案し, 工業的使用条件下でその実用性を検討した。

本研究の成果をまとめると，つぎのようになる。

1）多連科によって称量物の質量を連続測定するさいに必 要な科量物の最小間隔 $d_{S}$ の幾何学的条件を示した。

2）多連科の出力波形に複数のピーク值が発生する問題を 不等分布荷重によるものと考元，特定の範囲内におけ る最大值をもって質量を推定する方式を提案した。

3）科量物の長さ $20 \sim 130[\mathrm{~cm}]$ に対して多連科による改 良型連続科量法を適用し, 多くの実験例で平均誤差率 $\pm 0.7 \%$ 以下が保証できるものの, 個々の测定点では この範囲を逸脱するものがあった。

本研究では，科量物の長さに応じた多連秤の問題点を数理， 的，実験的に検証し，その実用性の限界を明らかにした。

\section{参 考 文 献}

1) R.Schwartz: Automatic weighing-principles, applications \& developments, Proceedings of XVI IMEKO World Congress (Vienna), 259/267 (2000)

2）公開特許公報：特開平 10-122940（1998），特許第 3249055 号 (2001), European Patent Application EP 0953828 A 1 (1999)

カタログ: OCS In-Motion Scales (OCS Checkweigher GmbH (Germany)) (Post-Expo 2002)

3) T. Nishiyama and C. Maeda: Shipboard Scale, ACTA IMEKO, 415/424 (1976)

4) C. Maeda and T. Nishiyama: Dynamics of a Shipboard Scale, ACTA IMEKO, 105/114 (1982)

5) C. Maeda and R. Masuo: A Shipboard Scale of Electromechanical Type Using Strain-Gage, IMEKO TC 3 Kobe, 169/174 (1984)

6) C. Maeda and R. Masuo : Electric Type Shipboard Scale, ACTA IMEKO, 299/306 (1985)

7) C. Maeda and R. Masuo : Electric Type Shipboard Scale (New System by Measuring Oscillating Period of the Scale), ACTA IMEKO, 215/222 (1988)

8）田中正吾：船舶加速度外乱場での重量自動計測について, 計 測自動制御学会論文集, 29-1, 18/25（1993）

9) T. Ono: Applications of the Estimation Theory to Dynamic Weighing Problems, ACTA IMEKO-1976, 2, 425/ 434 (1977)

10）小野, 中島, 西口：レバー式重量自動選別機の動的補償一線形 推定理論の一応用一, 日本機械学会論文集, 43-396, 1744/1754 (1977)

11）小野, 島岡：速度・変位検出形質量動的推定システム, 計測自 動制御学会論文集, 20-4, 322/328 (1984)

12）小野，島岡：動的計測方式による質量測定，計測技術，12-2, 35/41 (1984)

13）孫，小野：線形信号検出機構のダイナミックスの相対補償, SICE 関西支部シンポジウム資料, 53/58 (1991)

14）孫, 藤岡, 小野, 長尾, 孝橋 : 床振動環境下に扔ける高速高精度 質量計測について, 精密工学会誌, 64-4, 567/572（1998）

15）孫, 藤岡, 小野, 長尾, 孝橋 : 床振動環境下に扔ける高速高精度 質量計測について（オンライン同定を用いない動特性補償手 法の提案), 精密工学会誌, 64-7, 1029/1034 (1998)

16）亀岡, 中谷, 小松, 内藤：質量計測に扔ける基䃂振動法, 計測自 動制御学会論文集, 35-5, 616/622（1999）

17）野田, 桜井, 山崎, 大西, 小林, 黒須：コンベアライン上での連 続秤量における精度の向上, 計測自動制御学会論文集, 38-9, 759/764 (2002)

18）田崎, 山崎, 大西, 小林, 黒須: 多連科によるコンベアライン上 での連続秤量, 計測自動制御学会論文集, 39-11, 1022/1028 (2003)

19) T. Yamazaki, et al.: Continuous Mass Measurement in Check weighers and Conveyor Belt Scales, Proceedings of IMEKO TC 3/TC 5/TC 20, Celle in Germany 295/301 (2002)

20) R. Tasaki, et al.: Technical Problems in Multi-stage Conveyor Belt Scale, Proceedings of APMF 2003/IMEKO TC 3, Shang-hai in China 145/153 (2003)

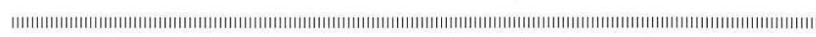

$$
\text { [著 者 紹介] }
$$

田 崎 良 佑 (学生会員)

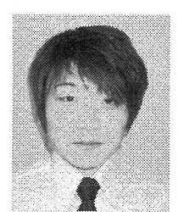
2004 年小山工業高等専門学校機械工学科卒業. 現在，京都工芸繊維大学工芸学部機械システム工 学科在学中.

\section{山 崎 敬 則（正会員）}

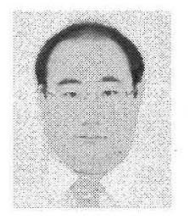

2000 年東京農工人学人学院生物システム応用 科学研究科博士課程修了. 同年東京農丁大学ベン チャー・ビジネス・ラボラトリー特別研究員. 2002 年小山工業高等専門学校助手. 工作機械の 運動制御，空調システムの制御などを研究。(博 士(工学))

\section{大西秀夫}

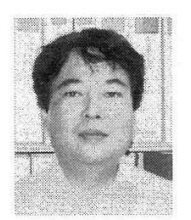

1980 年中央大学理工学部電気工学科卒業, 同 年新光電子 (株) 設計課勤務。現在，産業用計測制 御機器の開発設計に従事。

\section{小林 政 明}

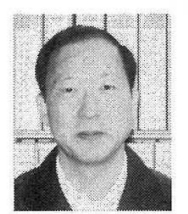

1972 年東京理科大学理学部応用物理学科卒業, 同年新光電子(株)設計課勤務。現在，差動トラン ス，変位測定制御機器の設計，音叉センサとそれ を利用したはかりの開発に従事.

黒 須

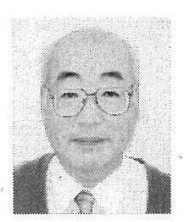

茂（正会員）

1962 年新潟大学工学部機械工学科卒業. 70 年 慶應義塾大学工学部(計測工学科) 助手, 74 年同 大学大学院博士課程 (計測工学専攻) 退学, 同年小 山工業高等専門学校講師，88 年教授. $78 \sim 80$ 年 カリフォルニア大学(バークレー校) 客員研究員. 2003 年同校退職。現在, クロテック(研究所)代 表, 空調システムの解析と制御に従事。(工学博 士) 